\title{
The State of International Migrant Children in Turkey: The Case of Van
}

\author{
Türkiye’deki Uluslararası Göçmen Çocukların Durumu: Van Örneği
}

\begin{abstract}
Abdurrahman YILMAZ*
Abstract: Turkey, due to its geographical position, is on the route of many types of migration and also shelters numbers of different migrants. These numerous migrants also include large numbers of children. The aim of this research was to examine the status of migrant children in Turkey, taking as an example the province of Van, located in eastern Turkey bordering Iran. Migrant children in Turkey are classified into two main groups, those living in satellite towns together with their family (usually of younger ages) and those (mostly at 14-17 years old) who are protected under the Social Services and Child Protection Agency because they have migrated without any companion. The findings reveal that most of the migrant children are from Afghanistan and the main reason for their flight was the security problems in Afghanistan and the worsening economic condition in Iran where they could not obtain either a residence or an education permit. Both those children coming with their families and those unaccompanied take the first help on applying for asylum and sheltering from the previous migrants. Applying to the UNHCR or to another Non-Governmental Organization not only serves as a starting point of the asylum procedure but also these applications in this respect serve to guarantee their presence and safety in this country.
\end{abstract}

Keywords: Migration, Child Migrants, Unaccompanied Minors, Turkey, Van

Öz: Türkiye coğrafi konumu nedeniyle hem farklı göç türlerinin güzergahı üzerinde bulunmakta hem de farklı göçmen kitlelerini barındırmaktadır. Bu göçmen kitleleri içerisinde ciddi sayıda çocuk göçmenler de bulunmaktadır. Bu araştırmada, Türkiye’de bulunan çocuk göçmenlerin durumu Türkiye'nin doğusunda, Türkiye-İran sınırında bulunan Van örneğinde incelenmiştir. Türkiye'deki çocuk göçmenler, geçici sığınmacı statüsünde aileleriyle beraber uydu kentlerde yaşayanlar (genellikle daha küçük yaşlardakiler) ve refakatsiz olarak göç etmeleri nedeniyle Sosyal Hizmetler ve Çocuk Esirgeme Kurumu'nda korumaya alınmış olanlar (çoğunluğu 14-17 yaş grubunda) olmak üzere iki ana grupta yer almaktadır. Araştırma sonuçlarına göre Türkiye'de bulunan çocuk göçmenlerin büyük bir bölümünü Afganistan'daki güvenlik sorunları ve ekonomik şartların giderek kötüleştiği İran'da oturma ve eğitim imkanları bulamayan Afganlıların oluşturduğu görülmektedir. Gerek ailesiyle beraber gelenler gerekse yalnız gelen yetişkin göçmenler hem barınma hem de sığınma başvurusu konusunda ilk yardımı genellikle daha önce gelmiş olan göçmenlerden almaktadırlar. Göçmen aileler ve çocuklar için BMMYK'liğine ya da bir sivil toplum kuruluşuna ulaşma sadece sığınma başvurusuna yönelik yasal işlemlerin başlatılması anlamına gelmemekte, bu yönde yapılan başvurular, öncelikle ülkede bulunmanın ve buradaki güvenliklerinin garanti altına alınması anlamını taşımaktadır.

Anahtar sözcükler: Göç, Çocuk Göçmenler, Refakatsiz çocuklar, Türkiye, Van

\footnotetext{
*Dr., Researcher, Bolu, ayilmazz@hotmail.com
} 


\section{Introduction}

Migration has been a constant of and remains an ongoing part of human history. It is a reality more frequently seen today due to improved and increased communications and easier means of transportation. People wish to move towards those places where they think they would have better living conditions for any number of reasons. Children are also participants in all migrant groups, within those groups of cross-border migrants, including asylum seekers/refugees and amongst the Internally Displaced Persons, and also including those mostly young males and females who migrate to work elsewhere for financial reasons. During these migrations children experience a very tough time, an experience that is very difficult for adults; the chidren sometimes together with their families or relatives, accompanied, but sometimes unaccompanied, lacking any protection. Throughout this period of migration, children may suffer for a number of reasons, for example, negligence and insufficiencies while they are exposed to trafficking. Children who have to migrate for any reason may be abused in a number of different ways. In Turkey, one finds a variety of migration types, from asylum seekers ("an asylum-seeker is someone who says he or she is a refugee, but whose claim has not yet been definitively evaluated", UNHCR, 2001, 23)/refugee (a refugee is "is someone who "owing to a well-founded fear of persecution for reasons of race, religion, nationality, membership of a particular social group or political opinion, is outside the borders of his/her nation, and is unable to, or owing to such fear, is unwilling to avail himself of the protection of that country", 1951 Convention Relating to the Status of Refugees, Article 1, BMMYK, 2001, 23) to the irregular migration types. Children are found amongst all of these types of migrant groups.

In this study, the status of child migrants in Turkey is analyzed, using the example of the Province of Van. The article, firstly, draws the international and national legal framework of child rights and the main problematic areas in respect to migrant children and unaccompanied minors. After setting out the conceptual framework, the research aimed to find answers to questions such as, why and how children come to Turkey, what they experience during the course of their journey, what problems they encounter in Turkey, what are the educational oppurtunites and health care services that are provided for migrant children in Turkey.

\subsection{Legal Framework for the Concept “Child”}

\subsubsection{International Legal Framework}

According to "The Convention on the Rights of the Child" accepted in the General Assembly of United Nations (UN) on the $20^{\text {th }}$ of November 1989, every person under the age of 18 is accepted as a "child" (Article 1, UN, 1989). The legal basis of this Convention covering detailed rule, approach and application of the rights of children, is formed by the "Geneva Declaration of the Rights of the Child" published on September the 26 ${ }^{\text {th }}, 1924$ and the "Universal Declaration of Human Rights" published through the Decision of the United Nations dated the $10^{\text {th }}$ of December 1948 and numbered 217 A (III) (UN, 1924; UN, 1948). While the Declaration dated 1924 covers the actions to be taken to protect the child, the "Universal Declaration of Human Rights" states that the "Mothers and the child have the right to obtain special care and help", thus extending the coverage to include mothers (Article 25).

The "UN Convention on the Rights of the Child" not only establishes the basis for the rights of children but also stresses that those countries being a party to the Convention cannot discriminate between children on the basis of: race, color, nation, ethnicity, social origin-roots, property, sex, disability, birth or other status (Article 2/1). The party states must provide child asylum seekers/refugees with the same rights that are accorded to child citizens. In other words, 
being a child surpasses any other statute. Another significant principle in the Convention is the concept of "the best interests of the child" in all activities/regulations regarding the child (Article $3 / 1$ ). According to the article mentioned, in all decisions regarding the children which are taken, either by public or by private social institutions, by courts or the legislative power, must follow "the best interests of the child". The inspection and monitoring of the implementation of the provisions of the "UN Convention of the Rights of the Child" by the signatory countries are conducted by the Committee on the rights of the Child (CRC), established in relation to Article 43 of the same convention. The Committee reviews the reports of the signatory countries, performs monitoring and makes the necessary recommendations to the signatory countries after publishing their reports.

Across the European Union, the "Convention for the Protection of Human Rights and Fundamental Freedoms" accepted in 1950, and enacted in 1954, established the basis for human rights regulations in Europe (EU, 1950). However, accepting the rights of the child as a special convention first came into existence in 1996. The "European Convention on the Exercise of Children's Rights" was accepted in 1996 and enacted in 2002 and it covers those aged under 18 and aims to improve the rights of the child by considering the "best interests of the child" principle (Article 1/2, EU, 1996).

The common ground for all these conventions, principle and recommendation decisions is to regard children as being the most vulnerable and most sensitive group in society, due to the abuses they are exposed to within society, sometimes within their own families (violence, sexual abuse, etc.). In order to protect them, children are given preferential treatment by the experts trained in this respect, in all legal applications concerning them.

\subsubsection{Child Migrants in Turkish Law}

Provisions on the protection of the child and the rights of the child are stated in Article 41 and 61 of the Constitution of the Republic of Turkey (T.R, 1982). According to the Article 41 of the Constitution, "Every child has the right to benefit from protection and care, and to have and sustain personal and direct relation with his/her parents unless it is explicitly against the childs (his/her) best interests". According to Article 61 of the Constitution, "The State takes every measure to reintegrate the children in need of protection into the society". As understood, the Constitution does not discriminate between children on the basis of: nationality, ethnic origin, religion etc. In other words, all the children - regardless of their being a citizen of the Turkish Republic or not - staying within the borders of Turkish Republic for any reason, have the right to protection and shelter, regardless of whether they entered the country legally or illegally. This article puts also a responsibility upon the public agencies.

Additionally, according to the Constitution of the Turkish Republic (Article 90);

"International agreements enacted in order are accepted as statutory. People cannot apply to the Constitutional Court with the reason that they are against the Constitution. (Additional sentence: art. 7/5/2004-5170/7). In the case of disputes between International Agreements on fundamental rights and freedoms enacted in order and National laws on the same subject having different provisions, the provisions of international agreements are taken as the basis" (TR, 1982).

This Article of the Constitution obliges Turkey, which signed the "UN Convention on the Rights of the Child" at "the World Summit for Children" held in the Headquarters of the UN on the $20^{\text {th }}-30^{\text {th }}$ of September, 1990, and, which enacted the Convention following the approval of 
the Grand National Assembly Of Turkey (GNAT) on the 27.01.1995, to accept this as a domestic law. However, the GNAT has reserved the right to interpret Articles 17, 29 and 30 of the Convention within the framework of Treaty of Lausanne, which means it approved the Convention with qualifications concerning these three articles.

Although Turkey approved "The Convention on the Rights of the Child" in 1995, enacting a child protection law to enact the provisions of the convention, in line with its own requirement and in a way to offer solutions for these problems has taken almost 10 years after the approval of this convention. "Procedures and principles on the protection of the children in need of protection or forced to a crime, on guaranteeing their rights and health" have been regulated under the "Child Protection Law (Article 1)" since 2005.

\subsection{Child Migrants}

\subsubsection{Child Migration on an International Scale}

In 1990 the estimated number of migrants in the world was about 154 million, this number reached 175 million in 2000, 221 million in 2010 and 232 million in 2013 (UN, 2013a). According to the population data of United Nations Department of Economics and Social Affairs Population Division, nearly 52\% of the immigrant population are women, while $7 \%$ are refugees, and 15\% are children and the young people under 20 (UN, 2013b). When the number immigrant population under 20 is examined in terms of age groups, the largest percentage in this category comprises children and young people between 15-19 years old (Graphic 1).

Graphic 1. Number of migrants (under age 20) by age groups and years (Million/Year)

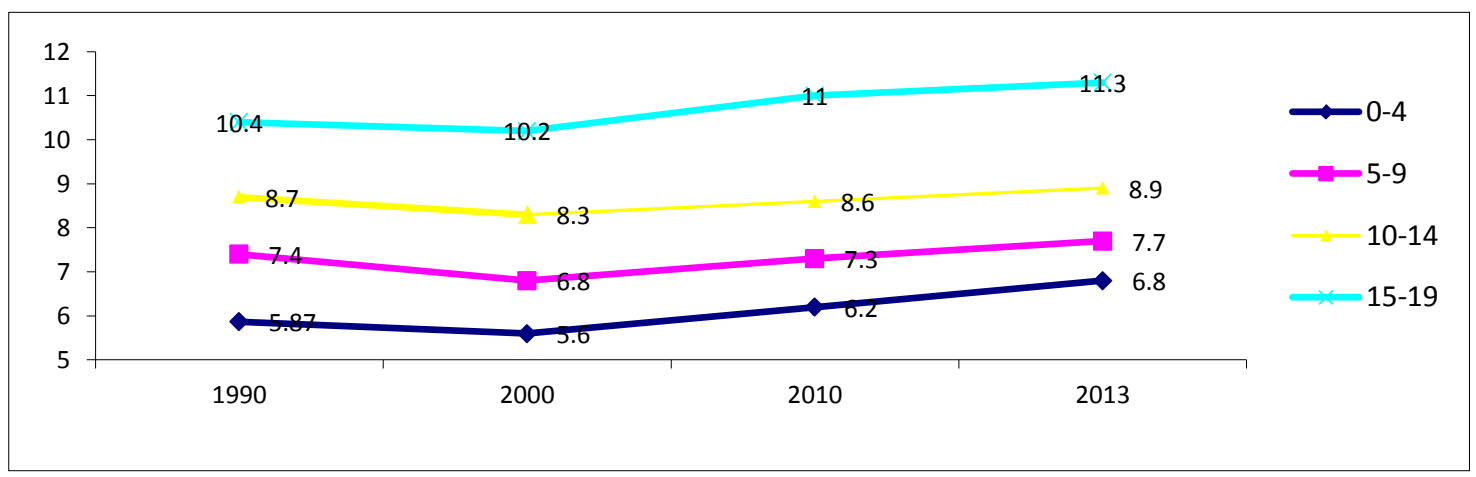

Reference: UN, 2013a

While children are afflicted by negligence or from insufficiencies during their migration, they are sometimes exposed to trafficking, while children who have to migrate for some reason are abused in different ways. According to the International Labor Organization (ILO), approximately 1.2 million children are exposed to human trafficking each year and the value in financial terms of this trafficking in children amounts to a minimum of several billion dollars (Figures are based on the 2005 data from the International Labor Organization. In the stated source, the total volume of human trafficking is estimated to be around 31.7 billion dollars including both adults and children, and the economic growth obtained through child trafficking is "at least several billion" considering that the number of children being trafficked amounts to half of the total human beings trafficked. Child Trafficking - Essentials. Accessed 20/01/2014. http://www.ilo.org). Children forced to take part in this process are exposed to sexual and other abuses including: early marriages, drug trafficking and manufacturing, mendicancy, home service and hard work in different work areas as a part of the labor force (Bokhari, 2008, 204). Human traffickers employ 
many methods to control and/or affect children, such as behaving like a friend, misdirecting them about the nature and conditions of the work, placing them under a large financial burden, and even employing sorcery or threatening the family members (Bokhari, 2008, 206).

Before, during and after migration, children often experience trauma, such as through the loss of family and adaptation problems which may impact upon their daily life. The risk factors for mental health problems in refugee children can be categorized into three aspects: Parental factors (maternal depression, torture, post-traumatic stress disorder (PTSD) in either parent etc.), child factors (number of traumatic events-either experienced or witnessed-expressive language difficulties at older ages etc., environmental factors number of transitions, poverty, cultural, etc.) (Table 1). According to research on refugee children arriving in Denmark, a family history of violence, such as the grandparents' violent death before the birth of the child or parental exposure to torture, in addition to a stressful current family situation are the strongest predictors of prevalent sleep disturbance in refugee children (Montgomery et alii, 2001, 18). All these experiences may cause children to have internalized, - anxiety, depression, emotional problems and the symptoms of post-traumatic stress - and externalized, health problems. Accoring to Derlyun and Broekaert's research on unaccompanied refugee children in Belgium, between 37\% and $47 \%$ of unaccompanied refugee youths have severe or very severe symptoms of internalised problems (Derluyn et alii, 2007, 141). The same research also suggests that among the unaccompanied refugee minor girls and adolescents-due to uncertainty about their future-are even more at risk of developing internalised problems (Derluyn et alii, 2007, 155).

Table 1. Risk factors for mental health problems in refugee children

\begin{tabular}{|l|}
\hline Parental factors \\
\hline Post-traumatic stress disorder (PTSD) in either parent \\
Maternal depression \\
Torture, especially of mother \\
Death of, or separation from, parents \\
Direct observation of the helplessness of parents \\
Underestimation of the stress levels in children by parents \\
Unemployment of parents \\
\hline Child factors \\
\hline Number of traumatic events-either experienced or witnessed \\
Expressive language difficulties \\
PTSD, leading to long term vulnerability in stressful situations \\
Physical health problems from either trauma or malnutrition \\
Older age \\
\hline Environmental factors \\
\hline Number of transitions \\
Poverty \\
Time taken for immigration status to be determined \\
Cultural isolation \\
Period of time spent in a refugee camp \\
Time in host country (the risk possibly increases with time) \\
\hline
\end{tabular}

Reference: Fazel et alii, 2002, 367.

This increases the importance of the asylum or social services where unaccompanied children are safeguarded. These social services should not only provide bath-bed-bread but also psychosocial and psychological care (Derlyun, et alii, 2008b, 327). According to Derlyun et alii, the 
"Asylum centre offers the largest number of the unaccompanied asylum-seeking children's network members and also the largest range of social support functions (social companionship, instrumental, informational and -in lesser amount- emotional support)" (Derluyn et alii, 2008a, 760). These social support functions are very important for children, especially for those coping with internalised problems. Wade et alii, suggest some key points for the social services to minimize the effect of migration such as: "safe and supportive place to live; continuities with past relationships, customs and cultures, and opportunities to create new ones; access to purposeful education and training; opportunities to move forward from troubling experiences, re-centre their lives, and find new purpose in everyday routines and activities" (Wade et alii, as Kohli cited, 2011, 315).

\subsubsection{Child Migrants in Turkey}

Turkey has met a different type of migration in consequence of the instabilities in the neighbouring countries following the collapse of the Eastern Block, globalization and the surrounding subsequent political, economic and military developments: transit migration. While the citizens of the unstable countries located to the East and South of Turkey try to pass through Turkey to the economically developed countries, Turkish citizens who want for economic and political reasons to leave the country have also joined this group.

The number of migrants in Turkey was 1.150 .000 in 1990 and reached 1.864 .000 in 2013 (UN, 2013b). The number of the asylum seekers and refugees has also increased, from 8.500 in 2000 to 39.000 in 2013 (In the figures provided by the UNHCR, it is stated that, "Because Syrians reside thanks to the temporary protection right introduced by Turkish Government, their number hasn't been reflected on the general statistics". In other words, the Syrian asylum seekers in Turkey, whose number reached 647.000, according UNHCR, 2014, are not included within these figures. UNHCR. Accessed, 22/02/2014. http://www.unhcr.org.tr/?page=12) and amongst these were in 2000, 1.095 and in 2013, 13.500 child asylum seekers and refugees. The current data shows that, one in three asylum seekers and refugees in Turkey is a child (UNHCR, 2002; UNHCR, 2013). According to data provided by the General Directorate of Security, 6.150 of the 34.000 migrants captured while entering or leaving Turkey in "illegal ways" or who had action taken against them as they were without residence permits were children in 2007 and this number was respectively 4.580 and 21.850 in 2011 (Topçuoğlu, 2012, 41).

Firstly we can classify child migrants in Turkey based upon their purpose in entering Turkey. Secondly, on whether they are accompanied or are unaccompanied. As stated above in the section concerning national and international regulations on the rights of the child, rights solely coming from being a child come first, prior to any other roles. In this respect, the reasons for migration should have a secondary importance. Since they will be subjected to different legal procedure and protection, evaluating migrant children in two different groups, the accompanied and the unaccompanied, is a more relevant way of categorizing these children.

Until the "Foreigners and International Protection Law" number 6458 which was prepared by the Ministry of Internal Affairs and enacted after being accepted in the General Meeting of GNAT on the 04.04 .2013 , there were no state organization dealing solely with migration issues and almost all of the migration questions had been handled by the General Directorate of Security. The "Foreigners and International Protection Law" foresees a one year transition period to enable it to establish its central and provincial organization. Even though it may take some considerable time to train its staff, this is a big step for Turkey. 


\subsubsection{The Province of Van and Migration: The Status of Adult and Child Migrants in the Province by Figures}

The Province of Van is the entrance point for those coming from East of Turkey because of its border location (Map 1). Migrants with the hope of reaching European countries use Van as a transit passing point, while Van is the city for a long residence for those who apply, particularly for asylum. The UNHCR office in the province has a particularly important function in the process of accepting asylum applications (Turkey signed the 1951 Convention and its 1967 Protocol with a geographical restriction. Because of this geographical reservation, Turkey does not recognise non-Europeans as "refugees". The evaluation and recognition process in Turkey is held by the UNHCR). In parallel with the applications and legal procedures across the country, the legal procedures of all adult migrants in Van are made in the Department of Foreigners Borders and Asylum under the Provincial Security Directorate, regardless of the underlying reasons (There are plans to open an agency of the General Directorate of Migration and a provincial director was temporarily assigned but was not active by March 2014). All migrants captured by the Land Forces responsible for border security, or by the gendarmerie or the police forces inside the country are submitted to the Department of Foreigners Borders and Asylum, if they have no criminal record. Migrants who do not apply for asylum are held in the Returning Center which is managed by the Department of Foreigners Borders and Asylum. They are kept there for a while until they are deported, together with those others from different parts of the country sent here to be deported. Transactions concerning the child migrants are also followed by the Department of Foreigners Borders and Asylum, however, the Children's Unit of the Provincial Security Directorate performs the transactions, while the shelter for children is provided by Child and Youth Center.

Map 1. Location of Van and the Routes followed by Migrants to Reach Van.

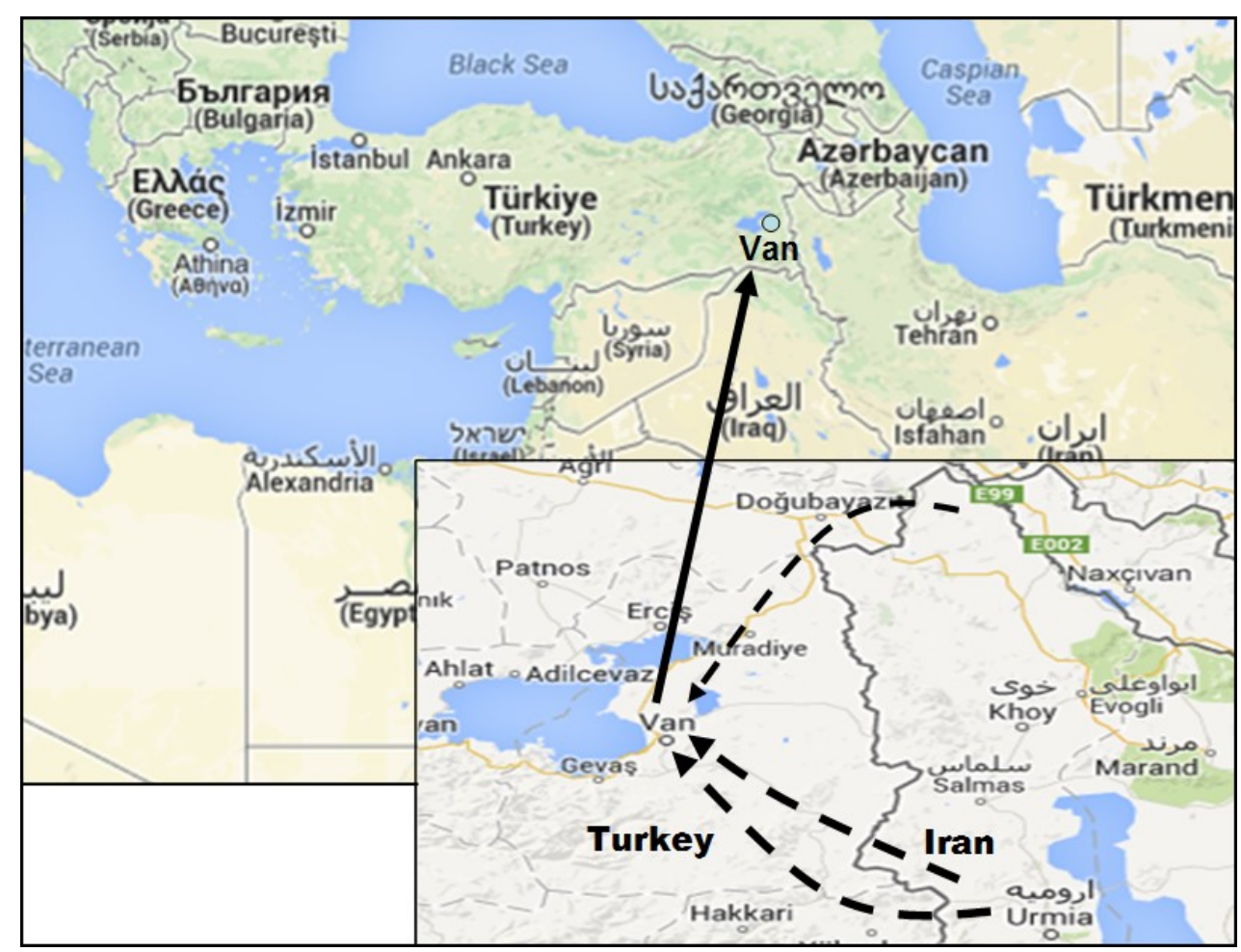


Table 2. Yearly Total Numbers of Migrants who Applied for Asylum in Van

\begin{tabular}{|l|l|l|l|l|l|}
\hline Year & Male & Female & Boy & Girl & Total \\
\hline $\mathbf{2 0 0 7}$ & 405 & 186 & 127 & 107 & 825 \\
\hline $\mathbf{2 0 0 8}$ & 663 & 420 & 346 & 284 & 1713 \\
\hline $\mathbf{2 0 0 9}$ & 252 & 214 & 178 & 174 & 818 \\
\hline $\mathbf{2 0 1 0}$ & 203 & 162 & 179 & 151 & 695 \\
\hline $\mathbf{2 0 1 1}$ & 239 & 100 & 94 & 58 & 491 \\
\hline $\mathbf{2 0 1 2}$ & 0 & 1 & 4 & 5 & 10 \\
\hline $\mathbf{2 0 1 3}$ & 98 & 98 & 96 & 77 & 484 \\
\hline
\end{tabular}

Reference: Department of Foreigners Borders and Asylum of Van Provincial Security Directorate, March 2014.

Table 3. Country of Origin of Migrants Who Applied for Asylum in Van

\begin{tabular}{|l|l|l|l|l|l|}
\hline Year & Afghanistan & Iran & Iraq & Other & Total \\
\hline $\mathbf{2 0 0 7}$ & 315 & 472 & 4 & 34 & 825 \\
\hline $\mathbf{2 0 0 8}$ & 1286 & 396 & 25 & 6 & 1713 \\
\hline $\mathbf{2 0 0 9}$ & 721 & 93 & 2 & 2 & 818 \\
\hline $\mathbf{2 0 1 0}$ & 600 & 65 & 7 & 23 & 695 \\
\hline $\mathbf{2 0 1 1}$ & 251 & 231 & 1 & 8 & 491 \\
\hline $\mathbf{2 0 1 2}$ & 9 & 1 & - & - & 10 \\
\hline $\mathbf{2 0 1 3}$ & 380 & 95 & - & 9 & 484 \\
\hline
\end{tabular}

Reference: Department of Foreigners Borders and Asylum of Van Provincial Security Directorate, March 2014.

Of the 484 migrants found in Van in 2013, 173 were child migrants (Table 2). A large proportion of these are Afghan migrants. Following the Afghans, Iranian migrants take the second place (Table 3). There are also others who are waiting in Van to be accepted by third countries although their asylum applications have been accepted. This means they have obtained the status of a refugee (Table 4, Being recognized as a refugee, does not mean that the refugees will be settled at once by refugee-accepting countries. The immigration policies of the refugee-accepting countries have non-written articles which enable them to act as the human resources department of their countries). When the routes migrants prefer to use to reach Van are considered, it is seen that they use both Van and Hakkari to enter Turkey (Map 1). 2500-3000 m. high mountains along the border between Turkey and Iran are hard obstacles to pass in any season of the year. Covering distances in this geography carries significant risks even during the spring and summer seasons, and is impossible to cross in winter because of avalanches, snow storms and temperatures hovering around minus 40. 
Table 4. Distribution of Migrants Waiting in Van to Reside in Third Countries by Nationality and Years

\begin{tabular}{|c|c|c|c|c|c|c|c|c|}
\hline $\begin{array}{l}\text { Duration } \\
\text { (Year) }\end{array}$ & $0-1$ & $1-2$ & $2-3$ & $3-4$ & $4-5$ & $5-6$ & $6+$ & Total \\
\hline Afghanistan & 3 & 233 & 4 & 22 & 39 & 50 & 33 & 384 \\
\hline Iran & 17 & 74 & - & 30 & - & 4 & 22 & 147 \\
\hline Iraq & - & - & - & - & - & - & 9 & 9 \\
\hline Somalia & 10 & - & - & - & - & - & - & 10 \\
\hline S.Arabia & - & 1 & - & - & - & - & - & 1 \\
\hline Total & 30 & 308 & 4 & 52 & 39 & 54 & 64 & 551 \\
\hline
\end{tabular}

Reference: Department of Foreigners Borders and Asylum of Van Provincial Security Directorate, March 2014.

\section{Purpose and Importance of the Research}

Migration, which has been and remains a permanent feature of human history, is a phenomenon increasingly encountered and more frequently observed today due to the possibilities provided through increased and rapid communications and transportation. People move toward the place where they think they will live a life in more comfortable circumstances for one reason or another, usually informed through returnees' accounts, media images and tales. Turkey is employed as a bridge for the migration from Asia and the Middle East into European Countries. She is also used as a shelter for those escaping pressure and conflict in their home countries because she is more stable when compared to these countries. The political and economic life of the world shows migration, for both financial reasons or due violent conflict, pressure and political reasons will continue without decreasing. Therefore, examining migration movements towards Turkey with regards to the migration types and migrant profiles has importance.

The aim of this research was to study the status of migrant children in Turkey. This subject had previously been addressed by only two researches (Helsinki Citizens Assembly, 2010; Topçuoğlu, 2012), to date, with this study employing the example of Van. It focuses upon the following main areas:

- Why and how children come to Turkey

- What they experience during their journey

- What problems they encounter in Turkey

- Their adaptation to the environment

- Protection provided due to being a child -

- If they benefit from the care services or not

- If the child's best interests are valued, when decisions are taken about them

- How they are provided with education and health

- An explanation of the problems encountered during migration and asylum procedures

\section{Method}

In this research, an informal conversational interview technique was preferred, for two main reasons. Firstly, due to the duration of stay in the area and, secondly, a direct question technique might have caused some trouble with the migrant people/families due to the sensitivity of the 
situation. As Kümbetoğlu points out, an informal conversational interview style "is beneficial for those staying in a specific area for a certain period of time and not aiming to obtain the required information from a single interview only. Compared to interview techniques, a person needs more time in the area in question" (Kümbetoğlu, 2005, 73-74). Considering the characteristics of the informal conversational interview technique, a formal question form was not prepared for the interviews with either the parents or with the unaccompanied migrant children. Interviews were held in a congenial, friendly atmosphere. However, the researcher determined the main research questions to be classified under the main heading of cultural elements, and to remember the main structure of the subject researched. During the conversation, the subjects that the interviewed people were eager to explain were carefully listened to, but the conversation was oriented towards the main subject through relevant questions when the interview deviated from its focus.

The subject of migrant children was been approached within two main subject categories:

- Those living with their families (accompanied)

- Those who have left their families (unaccompanied) and were under the protection of the Social Services and Child Protection Agency.

In addition to these two main categories of migrant children, there was a third category of participants who were interviewed during the research process; the head of the United Nations Refugees High Commissioner Van office, officials from the Department of Foreigners Borders and Asylum of Van Provincial Security Directorate, primary school principal and teachers, workers of the Social Services Agency, teachers of the Turkish Education Volunteers Foundation assigned to the education of child migrants. In addition to interviews and observations in the area, research techniques included a review of the literature, an examination of the legal framework and statistical data were also employed in this study.

As Hopkins stated, the research design is very important in conducting research with unaccompanied asylum-seeking children (Hopkins, 2008, 45). With this point in mind, this research project was designed so that ethical issues would be minimized. In order to accomplish this purpose, the research conceptual framework was developed as the first step, and subsequently the interviews with officials from the UNHCR, the Social Services Agency and teachers were made directly. The conceptual framework has been strictly followed and means of external observations were utilized in order to form an opinion as to the problems families and children encounter. In this respect, the training provided on the weekends by the Turkish Education Volunteers Foundation (TEGV) for the migrant children was attended and their relations with other children were observed. Information as to the developmental and linguistic problems of these children was obtained. After reaching a certain level, both conceptually and mentally, home-visits were made with an Iranian translator who had joined the training sessions of TEGV. In total, five families were visited during the research period, and face to face interviews were undertaken by the parents. Another part of this research comprised the interviews made with children under the protection of the Social Services and Child Protection Agency. Compared to the first group, this group was evaluated as being more sensitive and consequently the interviews with this group were not conducted at the same time as the first group. These interviews were only conducted after the conceptual framework for these interviews, as well as the hardships these children had been exposed to, were understood. Within this framework, in total, five children (one aged 14, two aged 16 and two aged 17) were interviewed.

In all stages of this research, the principles and guidelines stated in the "Code of Ethics of the American Anthropological Association (AAA)" were followed, in order to engage in 
developing and maintaining an ethical framework (AAA, 1998). In this respect, before beginning an interview, of particular importance, especially for the unaccompanied minors, was attached to gaining the "informed consent" of the migrants. Being aware of the fact that gaining the informed consent of a child is considered a serious issue in research, initally the social workers were interviewed and the purpose of this research was explained. Before the interviews were conducted with the children, the scope and the aim of this research was explained to them and extra care was taken to ensure that the children knew that they could refuse to answer particular questions and that they could leave the interview at any time they wished (Hopkins, 2008, 40).

During all of these interviews neither video nor sound recording facilities were utilized. Because of the unique characteristics of this research area, it was considered that demanding the making of video and sound recording of the interview would be entirely inappropriate and therefore no demand in this regard was given to the people to be interviewed. What was related during the course of the interview was written in a notebook, not to disrupt the interview and not to trouble the person being interviewed.

\section{Findings}

\subsection{Reasons of migration}

As the UNHCR's data indicates, the majority of asylum seekers/refugees are people from Afghanistan. Almost all of the Afghan asylum seeker/refugees questioned had migrated to Iran from Afghanistan years ago and they lived in a way in Iran and survived in peace together with their relatives. However, as a consequence of the economic embargo imposed upon Iran, due to the allegation that they are/have been developing nuclear weapons, the living conditions in Iran have plummeted. Behnam (Male, 25, Iranian) states that the "Toman (Iranian official currency) has lost one fifth of its value against USD within a month between April and May of 2012 because of the Embargo. USD has increased fivefold. Iran stated that it would provide aid to its citizens. Migrants didn't benefit from this aid. Therefore they found themselves in harsh conditions of Iran. Those with some money and with a relative in Europe goes there, when they "call" them. The poor can not go anywhere. However, only those with some money goes".

An Afghan father with three children, aged 3, 5 and 10 relates, they stayed in Iran for two years and during these years, he obtained work in construction etc. in return for daily wages, however Iran did not provide a residence permit and officials put "a lot of pressure" on them. They used to charge a 100 USD fee to the migrants for each six months (Celal, Male, 32, Afghan). Also, he did not believe that his children could obtain a good education in Iran. Before the children grew up, he wanted to go to a country where they could live in good conditions and where the children could benefit from a good education in the country where they live. Another family in similar circumstances has a 9 year old son and a 10 year old daughter. A couple, aged 30 and 28, got married in Afghanistan but, because they are Shia they suffered oppression in Afghanistan and they decided to migrate to Iran. After living for a while in Iran, their son, "Muhammed needed to go to school", and because they could not send him to school because they had no residence permit they decided to leave Iran.

Ebulfaz (Male, 37, Afghan), the father of four children, relates his reason for migration was the threats from the Taliban since he was working in the US military base in the city of Kunduz, Afghanistan. Once when they were going to work, a bazooka attack was directed at them and one of his friends lost his life in this attack. He adds that they had learned that the Taliban have his photograph and that he is wanted by the Taliban forces. In consquence, once his elder brother told him "you should go", they left at a night with only their clothes, without taking anything else 
with them.

İbrahim, an Afghan migrant, (Male, 32, Afghan) comes from a different situation: İbrahim was born in Iran and went to school for a long time there. His father was working for the public agencies in Iran and he even had Iranian citizenship. However, everything changed after 2000. Iran canceled the diploma, residence permit, citizenship etc. of the migrants and new rules and regulations were enacted by Iran for migrants:

"You have to obtain a residence permit every five months, and pay for this per individual (400 USD per person), and it is not certain that you will stay in Iran at that time, as they (Iranian officials) say that we can deport you. You have to also pay to register the children in schools. It is not like this in Turkey. As soon as you obtain the residence permit here, you can register your child in any school. I had a tailor's shop and everything was almost good, then they came and closed it, and sent us to another city" (Male, 32, Afghan).

However, this is not the main reason why İbrahim migrated. He met his wife seven years ago (2007), they are both Afghan but their ethnic roots are different. İbrahim is a "Hazāra" and his wife is "Pashtun". He states: "The Pashtun don't allow their girls to marry a Hazära man, therefore, her family didn't accept this marriage and they would have killed us if they catch us". After this clarification, the main difference between the Hazāra and the Pashtun became apparant, the sectarian differences. "There are four communities in Afghanistan: Tajik, Uzbek, Pashtun and Hazāra". The Hazāra belong to the 12'ver Shia, others are Sunni.

The one who is experiencing the hardest conditions amongst these migrant families is Bahar (45) who came to Turkey alone and who now has two children. Bahar is an Iraqi Kurd and lives in a "container" with her five year old twins, a son and a daughter (On the date of meeting, $22^{\text {nd }}$ of August 2013, most of the containers that had been used following the 7.2 magnitude earthquake of the $23^{\text {rd }}$ of October 2011, and which caused the deaths of 644 people and injured 1.966 people (AFAD, 2012) were vacant, only those living in very basic conditions lived in these containers). She worked in different places as a hairdresser. Bahar stated that the father of her children deceived her, saying that he was single. She realized that he was married when she was pregnant and decided to leave him, departing with her children. Bahar said she has a muscle fiber rupture in her left arm and she survives through help from her neighbours. Additionally, she obtained refugee status in 2008 or 2009, however no positive response has yet arrived from the countries that she has applied for, but, since she has been accepted as refugee, she has been receiving modest financial help from the UNHCR (90 USD monthly) for her family.

The reason for the migration of Yusuf (Male, 14, Iranian Kurd), a child migrant who arrived in Turkey after crossing the border alone, was the violence of his uncle. From his account, his parents died in a traffic accident when he was 2 years old. His uncle, with whom he was brought up, didn't register him for school but, instead, he made him work as a shepherd. He decided to escape his uncle's violence, saving some money to enable him to escape to Turkey.

Ahmet came to Turkey with his two uncles and a cousin. He said his father was killed by Taliban in Afghanistan, he lived in Iran for 10 months but he decided to come to Turkey because Iran doesn't give a residence permit. He plans to go near to his mother's brother who came to Turkey three years ago and is now working in Eskişehir as a construction worker.

The reason for Serhat's migration, who had crossed the border without any protection from a relative, was to be treated as unaccompanied (Male, 16, Afghan). Serhat is on insulin as he is a 
diabetic. Behnam (translator) understood that Serhat was born in Iran, while he speaks and he confirmed this. Serhat stated he was born in Iran and lived there until his father's death from the same disease, diabetes. Following the death of their father, the rest of the family went back to Afghanistan, Serhat, his mother and siblings. However, since there was no possibility of treatment for his diabetes in Afghanistan, he returned to Iran, leaving his mother and siblings in Afghanistan. He cannot do any heavy work, therefore he worked for a while as a tailor and he decided to go to Europe to obtain treatment.

Another unaccompanied migrant child is Hezrat (Male, 17, Afghan/Pashtun). The reason why Hezrat migrated was the economic conditions in Afghanistan. He plans to go on to Germany where one of his relatives lives. The other unaccompanied Afghan child who decided to migrate for financial reasons is Kasım (Male, 17, Afghan). Kasım lost his mother when he was only two years old and he lost his father in a bombing in their village 12 years ago. He had been living in Iran for 5-6 years and used to sing songs at weddings and work on construction sites in order to survive. Two to three years ago he decided to go to Europe and had been saving up the money for this.

\subsection{Their Arrival in Turkey}

Only one 14 years old child of the interviewed migrants said that he had actually walked across the border. All the others, both the families and the unaccompanied children crossed the border with the help of the migrant traffickers. There can be no doubt that those parents who had to cross the border with their young children were those ones who experienced the hardest conditions due to the weather and the topographical conditions. In this kind of situations, relatives are asked to help in walking part of the journey until they reach the meeting point for vehicles. A father who started off in the fall of 2012 with his three children aged 3, 5 and 10 related that he carried his little girl for 12 hours along a road and the other two children were helped by their uncle until they reached the meeting point for the vehicles. According to what he said, the meeting point is an area located between the city of Urumiye in Iran and the Hakkari/ Şemdinli/Yüksekova districts of Hakkari in Turkey. They went by car from that point.

Another family began walking with their 4 and 5 years old children in 2008. They had to climb very steep hills in a group of 50-60 people including Afghans, Pakistanis and Iranians in the course of a journey lasting 14 hours. There was a person leading this group with a stick and hitting those going slowly. This same person also wanted them to silence their children when they cried out, even to the extent of putting cloth in their mouths. When they came to the border of the Yüksekova district of Hakkari, they got into a minibus and went to Van.

Since these unaccompanied migrant children were aged between 14 and 17 they were more physically able to undertake the conditions of the journey and were less affected by the harsh conditions, when compared to the younger children. The Afghan Serhat (aged 16), began his journey in a group of 70 people and he relates they were seen by Iranian soldiers while they were crossing the border and the soldiers fired at them and so the people in the group dispersed and came together again after reaching the trafficker via cell phone. Serhat also entered Turkey through the region of Hakkari/Yüksekova and then went to Van by minibus from that point. Ahmet entered Turkey from Yüksekova and he was caught by Turkish soldiers, together with others in this group. Other unaccompanied migrant children also relate they entered Turkey through the Yüksekova region and then went to Van by minibus and then after that to Istanbul.

\subsection{Payment Made to Traffickers and Method of Payment}

The payment made to the traffickers for trafficking migrants varies and is dependant upon the 
season, the expected risk involved in the journey and the precautions taken on the border. In determining these prices, in Iran example, the devaluation of the Toman against the USD due to the sanctions and embargo has been significant. The type of payment to the traffickers by migrants is based upon the guarantee for both parties, arriving at the target point for migrants, obtaining the money for the traffickers in return for this service. In other words, migrants try to guarantee the money and the traffickers try to guarantee the service in return. The most basic method developed for this is to pay the trafficker when the migrant telephones his/her family and tells that he/she has reached the target point. With this method, the migrant doesn't carry the money. When they reach the agreed point and the migrants are sheltered, they are allowed to call their families by phone. The payment is made to the trafficker or to his close friend by a relative of the migrant and the migrant is allowed to go, upon receipt of the payment by the trafficker, or he/she waits for another target point.

The majority of the migrants interviewed in the course of this research said they either paid or had agreed to this method. For example, the unaccompanied child migrant called Serhat (aged 16, Afghan) said that he had to deliver the money in advance, because he was assessed as being at risk of "escape". Hüseyin having migrated with his three children pointed out that everybody went to a hotel upon arrival at Van. Only those who had paid the amount were allowed to leave the hotel. He had to pay the money first and only afterwards did he have the possibility of leaving the hotel. İbrahim (aged 32, Male, Afghan), who made an agreement to be taken to İstanbul together with his wife, said that: "They took us to a basement of a house in Istanbul where we went downstairs and it had also a basement. I called my brother from that basement and we were only allowed to leave the place after my brother had paid the money to the traffickers". Ebulfaz begun his journey with his four children, stated they agreed to travel to Turkey along the route through Afghanistan-Pakistan-Iran-Turkey and he was taken to the UNHCR by the traffickers when they reached Van and the payment was made in Afghanistan upon his call to confirm his arrival in Turkey. Another named Ahmet (Male, aged 16, Afghan) stated they agreed to pay on telephone confirmation after arriving in Van. However since they were caught in Yüksekova, his family didn't pay at all.

The amount paid for crossing the border, or reaching the target point, varies between 500 and 1000 USD. Of the unaccompanied children, Ahmet negociated a fee of 650 USD, while Kasim negociated 500 USD for the journey from Iran to Van. For the journey from Iran to Istanbul, Serhat paid 1000 USD in cash, while Hezrat agreed to pay 1500 USD upon telephone confirmation of his arrival. For the families migrating with their children, an adult fee is demanded for two or three children. Hüseyin (aged 30, Afghan) stated he agreed to a price for three adults, his two children, his wife, and himself, in October of 2008 and paid 600 USD per person for arriving at Van from Iran. Celal having started off from Iran in the fall of 2012 with his wife and two children had paid 1000 USD in total. Ebulfaz (aged 37) agreed with the traffickers a fee of 1100 USD per person to reach Turkey via Pakistan, Afghanistan and Iran said they had paid one adult fee for his four children in addition to the adult fee for himself and his wife (3300 USD in total). The couple, who decided to escape to Turkey because their families didn't consent to their marriage, paid 1000 USD each to reach Turkey via the TehranVan-İstanbul route.

\subsection{Their Experiences in Turkey: First Days, Legal Processes}

Both those coming with their families and the unaccompanied children received their first help for asylum applications and shelter from the previous migrants. This was done through contacting their friends/relatives and the new people they meet, either at the mosque or the 
UNHCR. Celal (aged 32, Afghan), the father of three children, said that they had applied to the UNHCR with the help of a friend whom they knew before. Hüseyin (aged 30, Afghan) came to Turkey with his children, said he was able to leave the hotel after payment was made to the traffickers and went to the UNHCR by taxi the other day in order to apply for asylum. He met another migrant living in Van while he was waiting there and they had stayed at this person's house for about 15 days. İbrahim (aged 32, Afghan), on the other hand, who was taken to İstanbul by the traffickers said he went to an Azerbaijani mosque in Zeytinburnu, met the servant of the mosque and he rented a room in a house where another family was living thankful for the servant's help.

The status of children who arrived unaccompanied is slightly different. Several children who were caught crossing the border or within the city, were determined to be young in age during their legal process and legal action is taken against them. Others apply to the UNHCR and then directly to the Foreigners Department of the Provincial Directorate of Security and therefore their process continued, in line with their ages, since they are under 18 years of age. Yusuf (aged 14, Iranian Kurdish) having crossed the border alone said that he stayed in parks for a few days and then his legal procedure began after the owner of a restaurant where he had lunch called police and he was then transferred to the Child and Youth Center (ÇOGEM) in Van. Ahmet (aged 16, Afghan) who was caught, together with 25 other people, having crossed the border, said there were 5 other children like him under the age of 18 in the group. All of them were sent to the Van ÇOGEM, three of the five escaped from there and one was deported.

Hezrat (aged 17, Afghan-Pashtun) stated that he left Afghanistan for financial reasons and he said that nine of the eleven people he came with were deported because they were over the age of 18, while he and another child were taken to ÇOGEM. They were told that they would be provided with residence permits, but later the officials said that they would be deported. Serhat, a diabetic patient, reached İstanbul and stayed with the traffickers for 10 days on his way to reach Europe. He told the traffickers that he would apply for asylum and the traffickers told him to go to Ankara in order to apply for asylum. Therefore he applied to the UNHCR in Ankara and was sent to ÇOGEM in Aksaray. After a while this dormitory was closed and he was transferred to another dormitory in Burdur.

Applying to the UNHCR or to another non-governmental organization not only serves as a start in the asylum procedure but also applications serve in this regard to guarantee their presence and safety in the country. However, when the UNHCR office in Van was closed until May in 2013, following the 7.2 magnitude earthquake of the $23^{\text {rd }}$ of October, 2011, and which caused the death of 604 people, migrants were unable to benefit from such support and lost their trust in the agency. In addition to the legal protection of the UNHCR, in line with the procedure, they said that the Turkish Human Rights Foundation has also helped them a lot. The foundation provides help and information concerning legal rights, as well as providing solutions for those migrants in poor condition for reasons such as disease etc. Moreover, an officer of the Foundation joins the training sessions organized by the Turkish Education Volunteers at the weekends as a trainer.

\subsection{Shelter, Means of Living and Living Conditions}

The difficulties parents encounter to provide better living conditions for their children do not come to an end after crossing the border. Finding a place of shelter, earning money to provide food, finding a doctor and medicine in the case of disease or sick children are very difficult, even under normal conditions. This naturally becomes much more difficult in a country where 
your language is not spoken. The migrant families living in Van generally live in one or two storey houses located in a region named Castle Locality, where mainly the poorer people live. Celal (aged 32, Afghan) sheltering in a house with a wide yard in this locality looks after the 7080 cows of the landlord. He earns a 300 USD (700 TL) wage and 117 USD (250 TL) of this is taken as his rent and he is not even insured. Ebulfaz (aged 37, male, Afghan) also looks after animals and earns 234 USD (500 TL) caring for 70-80 cattle. He allocates 47 USD (100 TL) for his rent. And it is a fact that it is impossible for a family including four children to live with the money remaining after the rent for a month. This situation is unavoidably reflected in the living conditions: a poorly heating stove in the middle of the room used as oven and a room covered in the items given by the neighbours.

Another migrant family in the same area stays with their children in a house rented for 117 USD (250 TL). Hüseyin (aged 30, Afghan) said he works in three different workplaces but cannot get his money. Because the migrants do not have work permits and they do not want to be included in a legal process even when they are right, prevents them applying in legal ways for their indemnification. However, this injustice he faced, affected his wife Mrs. Hividar (aged 28, Afghan), her voice trembles while talking about these issues. Mrs. Hividar wanting to contribute to the family budget, cleans a house in return for $35 \mathrm{TL}$ per week.

Of the families interviewed, İbrahim (Male, aged 32, Afghan) and his wife Munise (Female, aged 24, Afghan) are the couple who have lived in Turkey for the longest period compared to the others and the couple have a 2 years old child. Their two cousins in Iran also joined them after İbrahim's brother died four years ago (in 2009). The older cousin went to school until the first grade in secondary school and the young one continues in the first grade of primary school. Since they had difficulty in providing for their basic needs, the older cousin (aged 17) had to leave school and work. He began working near İbrahim working as a tailor in the center of Van. İbrahim earnings 380 USD (800 TL) per month and pays 117 USD (250 TL) per month for the rent.

The 2011 Van earthquake caused serious housing problems, particularly in the winter months. The migrant families are as affected by these conditions, as much as the locals, if not more. About one year after the earthquake, families started to move into their houses leaving the containers. The container settlement was almost full when it was visited in May of 2013 while we could not see anyone there in August of 2013, other than the very poor, with nowhere else to go. One of these families is Bahar (Female, aged 45, Iraqi Kurdish) staying with her twin children. Mrs. Bahar gained the status of a refugee in 2008 or 2009. However, the United States of America and then Australia inspected her file, but did not give her residence permit. Mrs. Bahar cannot work due to the muscle fiber rupture in her arm, she is paid 90 USD (190 TL) monthly by the UNHCR since she has refugee status. Additionally, she sometimes receives some help from the Foreigners Department of the Provincial Directorate of Security or from the chief (the local governor).

In accordance with the "Police duty regarding the child is primarily performed by the child units of the police" (Art. 31) article of the Child Protection Law numbered 5395, the legal actions concerning children caught crossing the border or found inside the country are held by the Children Unit of the Provincial Directorate of Security. In other words, whatever their situations are, if the migrant caught is under the age of 18 or there is any doubt that he/she is under that age, the police forces are responsible for taking the required precautions and transferring the child to the Child Unit Directorate. All other transactions after this phase are carried out by the Child Unit Directorate based upon the "Regulation on Security General 
Directorate Child Unit Directorate/Child Bureau Establishment, Duty and Work" dated 13.04.2001. Previously these units provided shelter for the child in divisions named "Child Care Unit", but now these children are kept for legal process and are then transferred to the "Child and Youth Centers".

Children, following this phase, reside in Child and Youth Centers. The center aforementioned accepted 82 children in total, consisting of 74 Afghan and eight Iranian and Pakistani children between the ages of 13 and 17 who were brought to it in the period from April 2013 to November 2013. All of the children brought this center are male. The Van-ÇOGEM sheltered 18 children between the ages of 13 and 17 by November. Before September 2013, the children brought to ÇOGEM used to live there until their processes were completed (officials state that this take for a few months) and then they are transferred to certain dorms inside the country. In September, those children given the "boarding confirmation" stayed in the center. Following the "boarding confirmation", a budget has also been provided. The interviewed officials were saying that the number of children in the center might increase in forthcoming days.

Van-ÇOGEM, a new building outside the city, is a quite good shelter. Children stay in four people rooms and have a hall in which they watch TV together. There is no opportunity for sports activities in the center, but there is an ongoing project of an all-weather sports center nearby which will probably provide good opportunities for these children. On the other hand, some of the personnel who are assigned in ÇOGEM, work based upon the hours of courses, as if they are contract employees of the Public Education Directorate. This means that a university graduate works for USD 560 (1200 TL) per month. The psychologist working in the center is not always at the center, he comes once or twice per week. It is doubtlessly very important to address the psychological conditions of the children, in all actions taken against them. Although the employees work devotedly, it is very hard to provide a good level of recovery for these children with only the services stated above. It is necessary that the people to be assigned to the training and care of the migrant children or of others staying in ÇOGEM dorms, should be provided not only with better financial conditions, but also with work insurance.

Officials state that when the children join ÇOGEM, once it is understood that they will not escape, they are given basic cleaning materials (shampoo, tooth brush and tooth paste etc.) and with clothes etc. The children who were interviewed children also stated they do not have any problem in these issues. After this welcome, the children are taken to a health clinic to assess their age and undergo medical examination. However, this is not a standard process. Some of the children interviewed stated that they had not been taken for any health check. On the other hand, the required examination and treatment procedures are followed, as for example with Serhat (Male, aged 16, Afghan) with a diabetes, or Yusuf (Male, aged 14, Iranian Kurdish) with a toothache.

The main problem behind the age assessment is unique to Turkey. The age assessments performed in Turkey, especially during the judicial processes are based upon X-ray of bone development. Age assessment concerning children for migration or judicial or administrative actions based only upon bone development is an issue of criticism. When the ages of children are assessed, their mental development should also be considered. The procedure followed in Van is the same as it is everywhere else in Turkey. Children, where there is doubt about their age, are sent to hospital and an estimate is made about them within a \pm 2 year range (such as, $16 \pm 2$ ). In these cases, the margin of error should be to the benefit of the child. Interviewed officials stated that this assessment of age is the same in Van. 


\subsection{Educational Possibilities and Adaptation}

Whether he/she is an asylum seeker/refugee or located in Turkey for another reason, there is no obstacle to continuing at school from the enacted legislation. Previously the obligation to provide certificates of education to the school and the lack of an identity number to register in a school used to form a serious obstacle in registering at school for education, but these problems have mostly been solved due to the "Circular of Ministry of National Education on Foreign Students" numbered 2010/48 (MEB). This circular forms a guiding light for both families and for school officials. According to the provisions of this circular, in the event that the educational situation of the student in his/her country is impossible to determine, this is determined by a commission set up, and the child continues his/her education from the grade determined by the commission. A family with four children who arrived in Turkey last year (2013) stated that they registered their children (aged 11,9 and 7) in school in September, and the officials had suggested to them, "let's register all of them in first grade, we replace them next year based on their course points” (Ebulfaz, Male, aged 37, Afghan).

In Van, 33 migrant children and 12 children having the status of refugees or asylum seekers continue in primary and secondary schools. In interviews held with the principal and the teachers of a school in a district where the migrant families are densely settled, it was stated that the migrant children were registered based upon the provisions of the circular. Teachers said nothing negative concerning the adaptation of these children, although the rate of attendance of the migrant children is lower than that of the local students, and the teachers are not informed if the children leave the country for some reason. The interviewed elders of the migrant families said that they were waiting for their children to learn Turkish to register in a school. The teachers also indicated that they have not encountered any serious language problems in this regard and, if they have, they let the migrant students sit, together with another migrant student who had arrived earlier and speaks the same language.

On the other hand, in Van, there is no practice or teaching activity for "teaching Turkish and gaining occupational skills in School/agencies and public education centers" under the circular of the Ministry of National Education. The only support is the courses that are provided at the weekends by the Turkish Education Volunteers Foundation. This course of training gathering children within two different groups, pre-school and post-school is very useful, but there is no certain curriculum. The course and the activities of children during the pre-school period are given by a psychologist working for the Turkish Human Rights Foundation and an accompanying translator, an Iranian asylum seeker, while the course and activities of school age children are given by an Iranian asylum seeker who is a university graduate. The trainers in the program are so devoted however, that the program may sometimes be disrupted due to their private work and, most importantly, the fact that a prepared curriculum is not followed, which causes uncertainty as to the aim of program and that it reaches the required targets. Moreover, it is an important drawback, that there seems to be no time for the migrant children to come to know the other local children and do some activities together. On one day of training, when the migrant children were playing football on the AstroTurf, the newcomers forced them to leave the football field and these newcomers, children who define the others as a foreign group, as if they do not belong in this society, may be the cause of significant subsequent troubles.

In addition to the conditions of the school, the current situation of the family, their living problems, sharing a house with another family or living together with another family based upon migrant solidarity are some of the factors affecting the success of the children at school. One of the interviewed teachers gave as an example an account of the situation of a girl named 
Behnaz, who was very successful in courses: According to what the teacher said, Behnaz's house is frequently visited by guests and then she is not allowed to go to school but has to serve the guests. Behnaz told her friends that "you do not know the value of school" and she also said she would have liked to live in Afghanistan, if only the conditions there were better.

There is no continuing school amongst the children in the Child and Youth Center. The main reason for this is the language problem. Of the five interviewed children only the Iranian Kurdish Yusuf (aged 14) speaks a little Turkish. Generally, only two of the 19 children in the school could speak in Turkish by March 2014. One reason for this is that these children do not have the opportunity to get in touch with the society in the locality, being a little out of the city; while another reason is the fact that they do not feel obliged to learn a foreign language because all of their friends speak the same language (mostly Persian). In the Child and Youth Center free entrance and exit rules are in action. In other words, children may leave the center at different hours of the day. However, since they do not have any money to pay to ride on the minibus service or to eat outside, this is not something that is preferred. In order to solve the problem of the language used by the children, a translator with good Persian was employed in the center by the end of November 2013, to provide Turkish courses and to help others communicate with the children. The officials interviewed and the UNHCR Van Office manager said the children are encouraged to learn Turkish, and their future is in some way dependent on this ability.

\subsection{Health: Meeting Examination, Treatment and Medicine Needs}

Migrants, who set off with the intention of having a better life and obtaining a higher level of welfare in the future, are sometimes exposed to health problems, due to the weather and topographical conditions of their journeys, as well as from unhealthy living areas and from malnutrition due to financially straightened circumstances. Of the migrants interviewed in the course of this research, no one said they experienced any serious physical health problem during the course of their migration. Only Celal (aged 32, Afghan) said his 3 years old child had a common cold during the journey but she recovered once they reached Van. Serhat (aged 16, Male, Afghan), required continuous treatment due to his diabetics and he said he had never had a problem relating to his illness in the Child and Youth Centers, in either Aksaray or in Van, indicating the officials had provided insulin whenever he needed it.

On the other hand, it is extremely difficult to determine the extent to which migrants are mentally affected over the course of this process. A very different type of study is required to determine the rate and degree of Post-Traumatic Stress Disorder (PTSD) caused through migration on the minds/to the psychology of both the adults and the children from their differing experiences in the course of their migration. From the interviews, the issue that pressed down upon and affected the families and children the most was the waiting period for the results of asylum seeking applications, and their inability in consequence to foresee anything of their future during this waiting period. Another issue is their exposure to exploitation, i.e. work for unreasonably low wages and/or even not being paid for the work the have done due to their illegal status (since they think they will be unable to obtain their money for their work by legal means).

Hüseyin (Male, aged 30, Afghan) and Hividar (Female, aged 25, Afghan) living with their two children are the family amongst the interviewed, that exhibit the indicators of psychological problems. Hividar explained that her husband worked in construction but he was not paid for the work he did - her voice trembled and her eyes filling with tears. This was not the only problem affecting Hividar. She also stated her children were disturbed by others and she has nothing to 
protect her children against these others. One of the unaccompanied migrants Serhat (Male, aged 16, Afghan) said that he stayed in the Child and Youth Center in Aksaray for a while, had good relations with his friends and the employees there, however, he was then sent to Burdur and his close friend was sent to another province, after the dormitory was closed, and then he was transferred to Van after staying in Burdur for a few months, and the repeated transfers and losing the company of his best friend had, unsurprisingly, affected him in a negative fashion.

For general practices, there is no obstacle to the examination of migrants when they get sick. The sick migrant applies to the Foreigners and Borders and Asylum Department and then goes to a hospital, after obtaining the consultation note. For the payment of the medicine, there are two different methods used. If the medicines are not too expensive the migrants can pay for them, they pay the amount themselves. If they are not able to pay the cost of the medicine, they can apply to Provincial Social Help and Solidarity Foundation, to obtain the amount for the medicine. During the course of these interviews it was understood that the migrants know the procedures in respect of the medical examination and the obtaining of prescribed medicine and this information is circulated on the grapevine. While we were talking about this issue in an interview, they told that they do not have to apply to the Foreigners and Borders Asylum Directorate any more, but instead can go directly to the hospital with the identity number given to them (İbrahim, aged 32, Afghan).

In the case of disease, it sometimes happens that the migrant is treated with the identity number of a Turkish citizen (Bahar, aged 45, Iraqi Kurdish). Occasionally the cost of the examination and of the medicine is paid by the workplace owner, or by a neighbour (Hüseyin, aged 30, Afghan). Bahar, with a muscle fiber rupture in her left arm, said she is treated with the identity number of her neighbour and gets the medicine she needs in the same way. Bahar relates she still has pains and she needs to have an injection once a week. She stated that mostly the local governor paid for the injection and sometimes other people around her also helped her. A family pointed out that a hospital asked for USD 70 (150 TL) to treat their child who had a serious problem with his teeth, and they stated that they could not pay this amount of money, and then the owner of the workplace helped them and the owner took the boy to a dentist. However, they were not satisfied with the treatment he received and they therefore asked the help of an official in the Turkish Human Rights Foundation and in consequence the treatment was accomplished (Hüseyin, aged 30, Afghan, Hividar, aged 28, Afghan).

\section{Result}

Migration, regardless of type continues to affect the lives of increasing numbers of people in a multitude of ways. Unfortunately, there is simply no hope with the current events in Syria, war and insurgency and the unstable situation that has continued for long years in Afghanistan; together with unemployment, international embargoes and the exceedingly difficult living conditions in less developed countries, that these places will recover in the near future or within any foreseeable time frame. Although it is particularly difficult to prevent economic based migration, it is possible to prevent refugee migration and Internally Displaced Persons (IDP) since the reasons for these are political. However, this possibility depends upon humanitarian policies being followed by these states. At the same time, of great significance is determining the position of children sensitively within these policies, and, most importantly, the implementation of these policies.

As a result of this study concerning the child migrants in Turkey, the following recommendations are offered: 
1. The establishment of active mechanisms and independent auditing/inspecting agencies are required, to monitor the situation within the units/agencies where these children are understood to be protected from external dangers.

2. While the protection and care of these children is the primary necessity and all other issues steming from this should follow the best interests of these children, however, considering the fact that expert workers and/or volunteers can help in the realisation of this, those working in these child and youth centers should be strengthened, in terms of both their qualifications and in their numbers. Another tool in providing for the best interests of the child is to appoint legally authorized personnel to represent the child in the absence of parents; especially in respect to the decisions to be made within the asylum procedure, in medical treatment, education, and accommodation. This fundemantal piece is missing and there is the immediate need for the adoption and implementation of this measure.

3. Currently, some ÇOGEM employees provide temporary services. An assigned psychologist works one or two days per week at ÇOGEM. All the employees of ÇOGEM who are responsible for children - migrant or not - should be trained and insured experts and they should be selected from amongst those people who can establish close communication with the children.

4. Remarkably positive is that in Turkey there is the legal framework within which educational and health services are provided to all migrants. However, since it is limited to elementary and secondary education, the educational opportunities do not permit the migrant children to properly plan their future. In addition, they do need an intermediary education process, one centred about the preparation for school and for language learning. This missing part could be filled by the NGO's.

5. Further, there is a need for NGOs that can provide a more participative and migrant oriented service, specifically focusing upon the asylum seeker/refugee and child and woman migrants and responsible for their migration processes.

6. The UNHCR Van Office was closed immediately after the 2011 Van earthquake and it was reopened in May 2013. In this type of disaster situation, a period in which even the local community can hardly continue with their lives with the support of their relatives, the migrants do need, even more than in ordinary times, the support of agencies such as the UNHCR. It therefore seems reasonable to suggest it would have been more effective policy to have strengthened the office of the agency in the region, rather than closing it down, during such a difficult period for child migrants.

7. It is known that official data on migration is based upon the number of people (number of asylum seekers, number of refugees, etc.). This type of data considers each person an individual, but it ignores their roles as father, mother/brother/sister. Although these roles can have differences in the context of the different cultures around the world, they do assign some responsibilities to individuals. In each policy or application developed, these responsibilities should certainly be considered and some privileges must be awarded to family migrants. Providing those asylum seeker parents, who have applied for asylum, the opportunity to have a work permit or accepting the application of asylum as a work permit will help to prevent them from being exposed to abuse. This would also be of benefit to the health of their children.

Before anything else, it should be noted that migration is a social event. In this connection the biggest mistake made by contemporary states is the practice of regarding migration primarily in respect to its "security" dimension. As Hollfield states, international policies on migration 
should be oriented in three dimensions, namely: "control”, "international relations (sovereignty, national security and relation between foreign affairs and international migration)" and "adaptation of migrants (impact of migration on citizenship, political developments)" (Hollifield, 2000, 137-138). Consequently contemporary states through focusing upon only one of these dimensions when focusing upon the issue of international migration, is an entirely inadequate response, insufficient to generate any solution, and an approach that inevitably itself forms a part of the problem.

As a requirement in respecting the environment and living a life adapted to it, there are certain ethical principles to consider, regardless of the particular field. When it comes to migration and especially to the child migrants, these ethical principles attain an even greater importance. The ethical principles to be followed in this research focus upon both "migration \& child" and "the meticulous attitude". During this research, it needs to be remembered that the migrants' focus is upon the results of their applications and of what will happen to them, they are, so to speak, in limbo, in a waiting period. The researcher should be aware that this waiting period places a lot of pressure on the migrants and it is therefore important to listen to them and to share their problems, putting to one side the role of researcher. At the same time, the researcher should be careful that this does not lead to any false expectations concerning the migration procedure.

Above and beyond the child and women migrants in Turkey, those who migrate as families certainly need special attention. As has happened to migrants trying to reach Greece by the Aegean Sea reported daily on the news, an increasing number of migrants loose their lives during their migration by sea. This is definitely another interesting and a vitally important field of migration studies. In addition, research on the psychological state of the migrants is also very important, in order to be able to fill the existing gap, together with the related research in anthropology and sociology. It can be understood that a project combining these different disciplines in respect to these migrants could have a significant role in further clarifying this subject. 


\section{REFERENCES}

AFAD (Disaster and Emergency Management Presidency of Turkey). “Disaster Report: Earthquake in Van”. (2012). Accessed 01/12/2013. https://www.afad.gov.tr/TR/IcerikDetay1.aspx?ID=107 \&IcerikID=570

AAA (American Anthropological Association). "Statement on Human Rights". American Anthropologist, New Series, 49/4, Part 1 (1947): 539-543. Accessed 22/05/2014. http://franke.uchicago.edu/aaa1947.pdf.

AAA (American Anthropological Association). (1989). "Code of Ethics of the American Anthropological Association (Approved June 1998)”. Accessed 25/11/2001. www.aaanet.org/committees/ethics. Accessed April 30, 2014. http://www.aaanet.org/committees/ethics/ethicscode.pdf.

AAA (American Anthropological Association). (1999). "Declaration on Anthropology and Human Rights”. Adopted by the AAA membership June 1999. Accessed 22/05/2014. http://www.aaanet.org/ about/Policies/statements/Declaration-on-Anthropology-and-Human-Rights.cfm.

Bokhari, F. (2008). “Falling Through The Gaps: Safeguarding Children Trafficked into the UK”. Children and Society. 22, 201-211. Accessed 01/05/2014. DOI:10.1111/j.1099-0860.2008.00151.x.

Derluyn I., \& Broekaert, E. (2007). "Different Perspectives on Emotional and Behavioural Problems in Unaccompanied Refugee Children and Adolescents”. Ethnicity and Health, 12/2, 141-162. Accessed 01/05/2014. DOI:10.1080/13557850601002296.

Derluyn I., Broekaert, E, \& Mels, C. (2008a). "Social Support in Unaccompanied Asylum-Seeking Boys: A Case Study”. Child: Care, Health and Development, 34/6. Accessed 01/05/2014. DOI: 10.1111/ j.1365-2214.2008.00883.x.

Derluyn I., \& Broekaert, E. (2008b). "Unaccompanied Refugee Children and Adolescents: Tha Glaring Contrast Between A Legal And Psychological Perspective”. International Journal of Law and Psychiatry. 31: 319-330. DOI:10.1016/j.ijlp.2008.06.006.

EU (European Union). (1950). "Convention for the Protection of Human Rights and Fundamental Freedoms”. Accessed 10/12/2013. http://conventions.coe.int/Treaty/en/Treaties/Html/005.htm.

EU (European Union). (1996). “European Convention on the Exercise of Children’s Rights”. Accessed 10/12/2013 http://conventions.coe.int/Treaty/en/Treaties/Html/160.htm.

Fazel, M., \& Stein, A. (2002). “The Mental Health of Refugee Children”. Archives of Diseases in Childhood. 87, 366-370. Accessed 09/05/2014. DOI:10.1136/adc.87.5.366 2002 87, 366-370.

HCA (Helsinki Citizens Assembly). (2010). “Childhood on Hold: Conditions and Treatment of Seperated Minor Refugees in Turkey”. Accessed 19/05/2013. http://www.hyd.org.tr/?pid=928.

Hollifiled, J. F. (2000). "The Politics of International Migration: How Can We "Bring the State Back in” Migration Theory Talking Across Discipline. Eds.: C. B. Brettel and J. F. Hollifield. New York and London: Routledge.

Hopkins, P. (2008) "Ethical Issues in Research with Unaccompanied Asylum-Seeking Children", Children’s Geographies, 6, 1 37-48, Feb. Accessed 05/2013. Doi:10.1080/14733280701791884.

Kohli, R. K. S. (2011). "Working to Ensure Safety, Belonging and Success for Unaccompanied AsylumSeeking Children”. Child Abuse Review, 20, 311-323. Accessed 01/05/2014. DOI:10.1002/car.1182.

Kümbetoğlu, B. (2005). Sosyolojide ve Antropolojide Niteliksel Yöntem ve Araştırma (The Qualitative Research Methods in Anthropology and Sociology), Bağlam: İstanbul.

Montgomery, E. \&, Foldspang, A. (2001). "Traumatic Experience and Sleep Disturbance in Refugee Children From The Middle East”. European Journal of Public Health, 11/1, 18-22. Accessed 09/05/2014.

Topçuoğlu, A. R. (2012). "Profiling Migrant Children in Turkey, Social Policy and Social Work Suggestions a Rapid Assessment Research”. Accessed 22/02/2014. http://www.turkey.iom.int/documents/Child/ IOM_GocmenCocukRaporu_tr_03062013.pdf.

Turhish Republic. (1982). “The Consitution of the Turkish Republic”. Accessed 12/12/2013. http://www. tbmm.gov.tr/anayasa.htm.

UN (United Nations). (1924). “Geneva Declaration of the Rights of the Child”. Accessed 01/12/2013. www.un-documents.net/gdrc1924.htm.

UN (United Nations). (1948). “The Universal Declaration of Human Rights”. Accessed 01/12/2013. 
http://www.un.org/en/documents/udhr/.

UN (United Nations). (1989). “The United Nations Convention on the Rights of the Child”. Accessed 19/05/2013. http://www.unicef.org.uk/Documents/Publication-pdfs/UNCRC_PRESS200910web.pdf.

UN (United Nations). (2000a). "Protocol Against the Smuggling of Migrants by Land, Sea and Air, Supplementing The United Nations Convention Against Transnational Organized Crime”. Accessed 21/05/2013. http://www.unodc.org/documents/treaties/UNTOC/Publications/TOC\%20Convention/TOC ebooke.pdf.

UN (United Nations). (2000b) "Protocol to Prevent, Suppress and Punish Trafficking in Persons, Especially Women and Children, Supplementing The United Nations Convention Against Transnational Organized Crime”. Accessed 21/05/2013. http://www.unodc.org/documents/treaties/UNTOC/Publications/ TOC\%20Convention/TOCebook-e.pdf.

UN CRC (United Nations Commitee on the Rights of the Child). (2012). "Consideration of Reports Submitted by States Parties under Article 44 of the Convention, Concluding Observations: Turkey, 20 July 2012”. Accessed 12/05/2013. http://www2.ohchr.org/english/bodies/crc/docs/co/CRC_C_ TUR_CO_2-3.pdf.

UN DESA (United Nations Department of Economic \& Social Affairs). (2013a). "Trends in International Migrant Stock: Migrants By Age and Sex”. Accessed 18/01/2014. http://esa.un.org/unmigration/ TIMSA2013/migrantstocks2013.htm?mtotals,

UN DESA (United Nations Department of Economic \& Social Affairs). (2013b) "Trends in International Migrant Stock: The 2013 Revision”. Accessed 22/02/2014. http://esa.un.org/unmigration/TIMSA2013/ migrantstocks2013.htm?mtotals.

UNHCR (United Nations High Commisioner for Refugees). (2001).The State of The World Refugees: 50 Years of Humanitarian Aid" Ankara: Başkent Matbaası.

UNHCR (United Nations High Commisioner for Refugees). “2002 UNHCR Statistical Yearbook”. 2002. Accessed 22/02/2014. http://www.unhcr.org/414ad5b10.html.

UNHCR (United Nations High Commisioner for Refugees). (2013). "UNHCR Turkey's Statistics by December 2013”. Accessed 22/02/2014. http://www.unhcr.org.tr/?page=12.

UNHCR (United Nations High Commisioner for Refugees). (2014). “Syria Regional Refugee Response”. Accessed 02/02/2014. http://data.unhcr.org/syrianrefugees/country.php?id=224. 